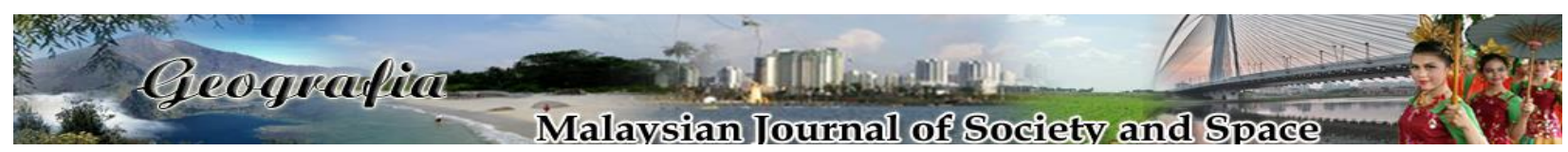

\title{
Pandangan pesakit wanita HIV terhadap kematian
}

\author{
Mashrom Muda \\ Akademi Pengajian Melayu (APM), Universiti Malaya \\ Correspondence: Mashrom Muda (mashrom@um.edu.my)
}

Received: 15 November 2019; Accepted: 22 November 2019; Published: 25 November 2019

\begin{abstract}
Abstrak
Penularan wabak Human Immunodeficiency Virus (HIV) dan Acquired Immune Deficiency Syndrome (AIDS) yang melibatkan kaum wanita di seluruh dunia kini menjadi kebimbangan baharu kerana peningkatan bilanganya setiap tahun. Di Malaysia, penularan wabak ini juga turut meningkat terutamanya yang melibatkan golongan suri rumah dan gadis remaja. Golongan wanita berisiko tinggi menyebarkan HIV positif kepada orang lain melalui hubungan seks (suami HIV negatif) dan bayi dalam kandungan. Wanita yang dijangkiti HIV positif mempunyai pandangan yang berbeza terhadap apa yang berlaku dan kebanyakan pandangan-pandangan ini bersifat negatif. 'Kematian' adalah pandangan yang paling banyak diperkatakan oleh wanita yang menghidap HIV positif. Pandangan-pandangan yang diberikan oleh penghidap wanita ini memerlukan satu perbincangan tentang mengapa mereka beranggapan sedemikian. Sehubungan dengan itu, artikel ini bertujuan untuk membincangkan bentuk-bentuk pandangan oleh wanita Melayu setelah disahkan sebagai penghidap HIV positif. Kajian ini menggunakan data primer dan data sekunder. Data primer diperoleh melalui temubual secara mendalam kepada 20 orang informan terdiri daripada wanita telah dijangkiti HIV positif yang menetap di sekitar Besut (Terengganu), Pasir Puteh, Bachok dan Kota Bharu (Kelantan). Manakala data sekunder berbentuk kajian lepas, jurnal-jurnal dan statistik telah digunakan. Kajian ini mendapati bahawa, rata-rata informan memberi pandangan negatif dan mengaitkan HIV positif dengan 'kematian' serta perkara negatif lain seperti jangkitan 'orang benci', 'orang hina' dan 'orang malu'. Kekurangan maklumat atau mendapat maklumat yang salah menjadi punca kepada pandangan ini. Baik atau buruk pandangan oleh penghidap boleh mempengaruhi proses pemulihan dan pemerkasaan diri mereka.
\end{abstract}

Kata kunci: HIV positif, kematian, pandangan, sumber maklumat, pengetahuan, wanita. 


\title{
The perception of HIV women patients on death
}

\begin{abstract}
The spread of the Human Immunodeficiency Virus (HIV) and Acquired Immune Deficiency Syndrome (AIDS) outbreak affecting women around the world is now a new concern due to the increasing number of casses each year. In Malaysia, the outbreak has also increased especially involving housewives and teenage girls. The women are at high risk of transmitting HIV positive to others through sex (husband HIV negative) and the unborn baby. Women who are infected with HIV positive have different views on what is happening and most of these views are negative. 'Death' is the most widely spoken view of women living with HIV positive. The views given by these women sufferers need a some discussion as why do they think so. Therefore, this article aims to discuss the forms of views by the Malay women after they were diagnosed as HIV positive. This study uses primary and secondary data. The primary data were obtained through in-depth interviews of up to 20 informants including women with HIV positive living in Besut (Terengganu), Pasir Puteh, Bachok and Kota Bharu (Kelantan). While the secondary data is in the form of previous studies, journals and statistics were used. The study found that the informants gave negative views and associate HIV positive with 'death' and other negative things such as 'infections', 'hate', 'humiliation' and 'embarrassment'. Lack of information or misinformation is the cause of these views. Good or bad, views by the sufferers can affect their recovery and empowerment process.
\end{abstract}

Keywords: HIV positive, death, views, information, knowledge, women

\section{Pengenalan}

Wabak pemusnah daya ketahanan tubuh atau human immunodeficiency virus (HIV) dan sindrom kurang daya ketahanan melawan penyakit atau acquired immune deficiency syndrome (AIDS) yang berlaku kini sudah bersifat universal. Tiada negara, budaya, agama atau jantina yang bebas daripada wabak HIV positif dan AIDS pada hari ini kerana sifatnya yang semakin kompleks dan dinamik. Wabak ini bukan sahaja bersifat rentas sempadan, tetapi juga rentas jantina. Buktinya, kes yang melibatkan kaum wanita di seluruh dunia semakin meningkat setiap tahun, malahan ada ketikanya lebih cepat berbanding dengan lelaki (Andersen, 1997 dalam Aishah @ Eshah, 2002). Wabak HIV positif mempunyai reputasi yang buruk dan negatif kerana dianggap sebagai jangkitan yang boleh menyebabkan kematian dan masih belum ditemui penawarnya. Dijangkiti HIV positif juga boleh mendatangkan stigma serta diskriminasi kepada seseorang penghidap kerana HIV tidak sama seperti penghidap penyakit lain yang lebih mendapat perhatian dan rasa simpati anggota masyarakat. Hal ini adalah kerana, penghidap HIV positif sering kali dilihat sebagai golongan yang perlu dipinggirkan kerana dianggap sebagai golongan yang telah melanggar norma masyarakat dan terlibat dengan kegiatan yang tidak bermoral. Malahan, orang yang dijangkiti HIV positif dikatakan sebagai telah mendapat balasan atau hukuman daripada Tuhan (Aishah @ Eshah, 2002). Pandangan-pandangan oleh masyarakat secara tidak langsung turut mempengaruhi pandangan penghidap terhadap diri mereka sendiri. Maka tidak hairanlah sekiranya penghidap wanita mengaitkan HIV positif dengan kematian dan perkara negatif lain. 
Wanita yang dijangkiti HIV positif sebenarnya melalui pengalaman yang lebih teruk berbanding dengan lelaki. Ini kerana, apabila dijangkiti HIV positif penghidap wanita kehilangan kuasa membuat keputusan untuk memilih pasangan hidup, menentukan cara melakukan hubungan seks, mendapatkan rawatan dan sumber maklumat serta hak untuk mengetahui latar belakang lelaki yang ingin dikahwini (Puri, Tamang \& Shah, 2011; Winkvist \& Akhtar, 2000). Selain itu, penghidap wanita tidak mempunyai peluang sosial yang lain seperti pekerjaan yang baik, pendidikan tinggi, pendapatan dan kekayaan. Malah faktor ini telah dikenalpasti sebagai punca utama wanita mudah dijangkiti HIV positif (Mashrom \& Rahimah, 2015). Di negara-negara sedang membangun, wanita sering kali disubordinasi secara kolektif oleh ahli masyarakat lain dengan tidak diberikan peluang untuk mewakili bidang tertentu secara aktif dan sistematik seperti ekonomi dan pendidikan bagi meningkatkan taraf kehidupan mereka (Monagan, 2010). Kemiskinan juga boleh menggalakkan peningkatan masalah sosial seperti pelacuran dan penyalahgunaan dadah yang kedua-duanya merupakan punca utama jangkitan HIV positif. Ini ditambah pula dengan kekurangan kemudahan kesihatan dan sistem penjagaan kesihatan yang lemah, menyebabkan jangkitan tersebut sukar dikawal.

Dianggarkan lebih setengah daripada penduduk dunia, iaitu 3.8 bilion orang (keseluruhannya 7.7 bilion orang) tinggal di negara berpendapatan rendah, termasuklah Asia Pasifik (Khalid et al., 2010; Current World Population (CWP), 2019). Di sesetengah negara, jumlah penduduk wanitanya jauh mengatasi jumlah kaum lelaki. Kekurangan peluang pendidikan dan pekerjaan, secara tidak langsung boleh menjerumuskan kaum wanita ke kancah pelacuran. Ini kerana, di negara membangun kaum wanita lazimnya lebih sukar untuk mengatasi tekanan kehidupan berbanding lelaki atas sebab fizikal dan sosiobudaya. Gaya hidup moden yang bebas dan kurangnya kesedaran serta pengetahuan tentang jangkitan HIV positif turut meletakkan mereka kepada risiko penyakit tersebut. Berdasarkan situasi yang dijelaskan, artikel ini adalah bertujuan untuk mengenal pasti jenis-jenis pandangan oleh informan wanita terhadap HIV positif setelah disahkan sebagai penghidap. Selain itu, artikel ini juga bertujuan membincangkan faktor-faktor yang menyebabkan penghidap wanita Melayu mengaitkan HIV positif dengan kematian serta perkara negatif lain.

\section{Kajian literatur}

\section{Wanita dan HIV Positif}

Catatan kes HIV positif yang berlaku di seluruh dunia memperlihatkan bahawa sifatnya yang semakin kompleks dan merentasi sempadan. Ini kerana, kes HIV positif dan juga AIDS boleh dikesan di kebanyakan negara di dunia ini, termasuklah di Malaysia. Walaupun berlaku penyebaran ke seluruh dunia, jumlah serta kadarnya adalah berbeza-beza dan zon sub-Sahara kekal paling teruk terjejas dengan hampir 1 bagi setiap 20 orang dewasa yang hidup dengan HIV datangnya kawasan tersebut (Rajah 1). Malah kes yang berlaku di sub-Sahara menyumbang hampir 71.0 peratus daripada keseluruhan jumlah orang yang hidup dengan HIV positif di seluruh dunia (WHO, 2014). Pada tahun 2018, negara Afrika menyumbang sebanyak 25.7 peratus jumlah HIV positif di seluruh dunia berbanding 3.5 peratus di Amerika Syarikat (AS), 3.8 peratus Asia Selatan - Timur, 2.5 peratus di Eropah, 0.4 peratus Mediterranean dan 1.9 peratus di Barat Pasifik (WHO, 2018). Sebahagian besarnya adalah golongan wanita. 
Jangkitan HIV positif yang melibatkan golongan wanita di seluruh dunia telah meningkat setiap tahun lebih daripada satu dekad sehingga menjadi separuh daripada penyumbang iaitu sebanyak 50.0 peratus daripada jumlah keseluruhan penghidap dewasa (Loutfy et al., 2015). Sehingga tahun 2018, jumlah penghidap wanita ialah 18.8 juta orang iaitu meningkat sebanyak 0.6 juta orang daripada tahun 2017 (18.2 juta orang) dan 1.0 juta orang daripada tahun 2016 (17.8 juta orang) (WHO, 2016; 2017; 2018). Peningkatan demi peningkatan ini disumbangkan oleh gadis remaja dan wanita muda. Malah kelompok ini dikatakan mencatatkan nisbah 1:4 daripada jangkitan baru, terutamanya di zon sub-Sahara.

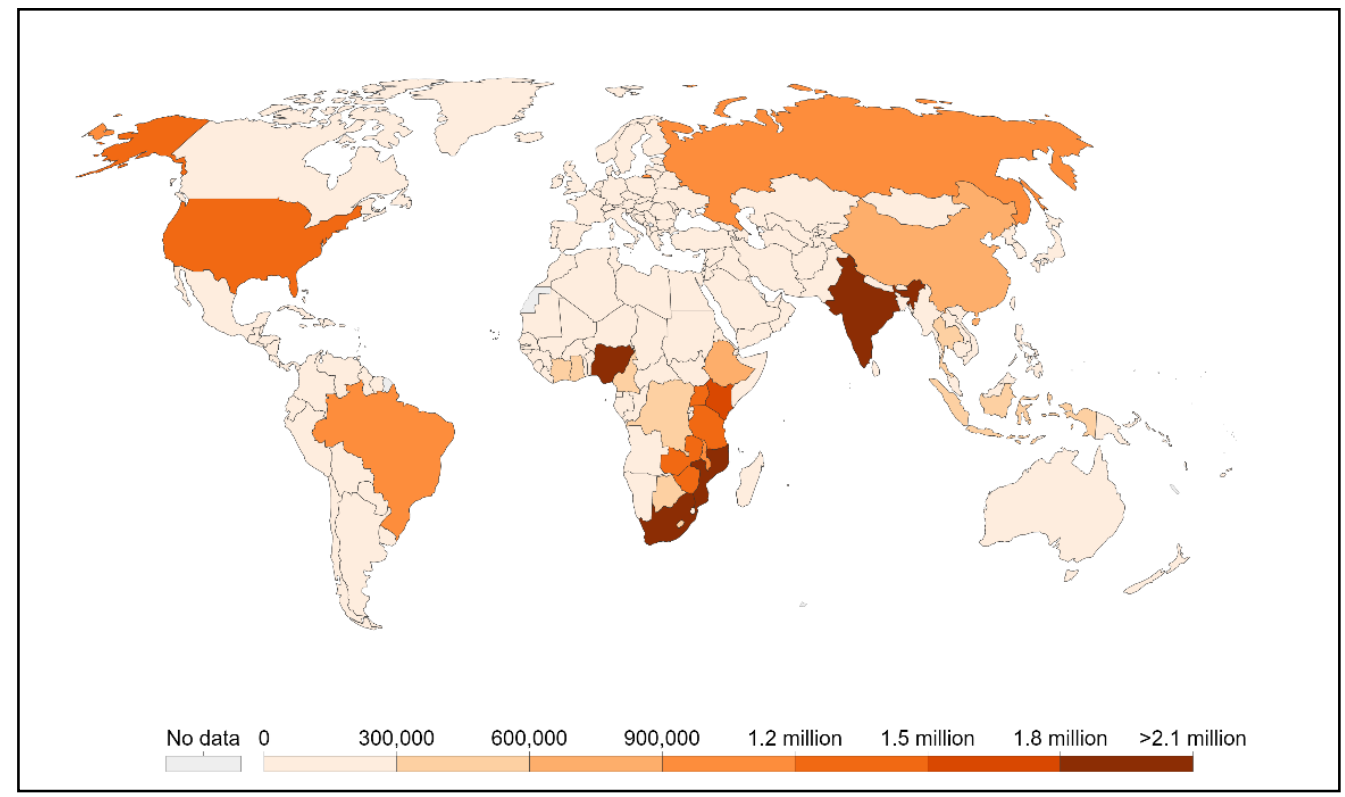

Sumber: Roser \& Ritchie, 2019

Rajah 1. Anggaran wabak HIV Positif di seluruh dunia tahun 2017

Negara-negara di zon sub-Sahara atau Afrika seperti Zimbabwe, Angola dan Tanzania, jumlah penduduk wanita yang dijangkiti HIV positif melebihi lelaki (UNAIDS, 2018). Manakala di negara maju seperti Amerika Syarikat (AS) dan Britain, jumlah jangkitan HIV positif dalam kalangan penduduk wanitanya juga turut meningkat, terutamanya melalui aktiviti heteroseksual. Perkembangan dalam aktiviti perdagangan seks atau seks komersial, menjadi punca utama jangkitan HIV positif dan AIDS terutamanya di Kepulauan Carribean sehingga wanita mudanya dikatakan mempunyai 2.5 kali ganda risiko untuk dijangkiti HIV positif berbanding dengan lelaki (UNAIDS, 2004). Perkembangan di benua Asia juga tidak jauh beza apabila menunjukkan peningkatan yang membimbangkan. Aktiviti pelacuran yang menjadi pilihan sebagai sumber kewangan akibat kemiskinan merancakkan lagi penyebaran kes HIV positif dalam kalangan wanita. Ada juga wanita yang dijangkiti HIV positif melalui suami yang curang kerana mempunyai hubungan seks di luar ikatan perkahwinan tanpa menggunakan kondom. Setengah suami yang lain pula berkongsi jarum suntikan ketika menagih dadah dengan penagih dadah lain yang telah dijangkiti virus HIV positif dan AIDS, memindahkan virus tersebut kepada isteri melalui hubungan kelamin. 
Jadual 1. Jumlah jangkitan HIV/AIDS di seluruh dunia tahun 2016 hingga 2018

\begin{tabular}{lccc}
\hline \multirow{2}{*}{ Perkara } & \multicolumn{3}{c}{ Anggaran (Juta Orang) } \\
\cline { 2 - 4 } & Tahun 2016 & Tahun 2017 & Tahun 2018 \\
\hline Individu Dengan HIV/AIDS & 36.7 & 36.9 & 37.9 \\
Dewasa Dengan HIV/AIDS & 34.5 & 35.1 & 36.2 \\
Wanita Dengan HIV/AIDS & 17.8 & 18.2 & 18.8 \\
Kanak-kanak Dengan HIV/AIDS & 2.1 & 1.8 & 1.7 \\
Individu Dengan Kes Baru HIV & 1.8 & 1.8 & 1.7 \\
Dewasa Dengan Kes Baru HIV & 1.7 & 1.6 & 1.6 \\
Kematian Disebabkan AIDS & 1.0 & 940,000 & 770,00 \\
\hline
\end{tabular}

Sumber: WHO, 2016; 2017; 2018

Situasi di Malaysia juga amat membimbangkan akhir-akhir ini walaupun trend yang direkodkan sentiasa berubah (meningkat dan menurun). Perubahan yang berlaku sebenarnya berkait juga dengan sifat HIV positif itu sendiri yang sentiasa berubah, unik, dinamik dan kompleks sehingga memaksa pihak KKM, badan-badan berkaitan HIV positif dan AIDS untuk sentiasa dalam keadaan kesiapsiagaan. Statistik dikeluarkan oleh KKM dan Malaysian AIDS Council (MAC) menunjukkan bahawa, pada tahun 2014 jumlah kes yang direkodkan ialah 3,517 orang menurun kepada 3,330 orang pada tahun 2015 dan meningkat kembali pada tahun 2016 menjadi 3,397 orang atau kes. Perubahan kes turut berlaku dalam kalangan penghidap wanita dari tahun 2015, 2016 dan tahun 2017. Pada tahun 2015, jumlah kes direkodkan ialah 512 orang menurun kepada 413 orang (2016) sebelum kembali meningkat kepada 457 orang pada tahun 2017 (KKM \& MAC, 2017).

\section{HIV Positif \& kematian}

Apabila seseorang individu didiagnosis sebagai pesakit HIV positif, banyak perkara ditakuti sehingga menjejaskan banyak aspek kehidupan mereka. Tidak cukup dengan itu, penghidap sering kali dalam keadaan kebingungan, terkejut (shock) dan penafian sehingga mewujudkan situasi untuk menarik diri daripada orang di sekeliling mereka. Penarikan diri ini berlaku kerana perasan takut dan bimbang distigma, didiskriminasi dan dilabel dengan pelbagai label negatif sehingga mereka sendiri memikirkan perkara seperti kematian.

Kematian adalah perkara pertama yang difikirkan oleh penghidap wanita apabila mereka disahkan dijangkiti HIV positif. Pandangan yang diberikan oleh mereka sebenarnya banyak dipengaruhi oleh sumber-sumber maklumat yang tidak tepat dan sahih seperti mendengar cakapcakap orang sekeliling termasuklah daripada orang kampung, rakan-rakan dan jiran. Maklumat melalui media massa dan elektronik turut mempengaruhi pandangan mereka terhadap HIV positif dan AIDS. Selain itu, ada juga yang mengaitkan HIV positif AIDS dengan kematian melalui pengalaman mereka sendiri yang pernah melihat atau mendengar kes tersebut sama ada yang melibatkan adik beradik, suami/pasangan, jiran atau rakan-rakan. Akibat terlalu sedih, takut, terkejut, bimbang dan risau turut menyumbang kepada pandangan ini selain mengaitkan HIV positif dengan perkara negatif lain.

Sesetengah anggota masyarakat juga mengambil pendekatan sama apabila sering kali mengaitkan HIV positif dengan kematian walaupun situasi pada hari ini sudah banyak berubah dan penghidap HIV positif boleh bertahan hidup sehingga 20 tahun lamanya dengan virus HIV dalam badan. Tidak dinafikan bahawa, HIV/AIDS dianggap sebagai penyebab utama kematian 
dalam kalangan penghidap sejak sekian lama (UNAIDS, 2004; WHO, 2009). Namun, akhir-akhir ini sahaja menampakkan pengurangan yang agak ketara dari segi jumlah kes kematian setelah adanya vaksin anti-retroviral. Walaupun tidak dapat menyembuh jangkitan HIV positif dan AIDS sepenuhnya, sekurang-kurangnya dapat memanjangkan umur penghidap dan mengurangan kes kematian. Bagi tempoh 10 tahun yang lepas, kes kematian akibat AIDS banyak dikesan dalam kalangan wanita yang berumur antara 25-34 tahun (Giffin \& Lowndes, 1999). Pada tahun 2017 pula, kelompok paling tinggi meninggal dunia akibat HIV/AIDS ini ialah 15-49 tahun dan menyumbang sebanyak 66 hingga 72 peratus daripada jumlah kematian di seluruh dunia (Roser \& Ritchie, 2019). Pada tahap umur ini dianggap sebagai tingkat umur produktif kerana mempunyai harapan tinggi dan sumbangan yang besar sebagai tenaga buruh atau sebagai penjaga (Doggest et al., 2015; Komwa et al., 2010).

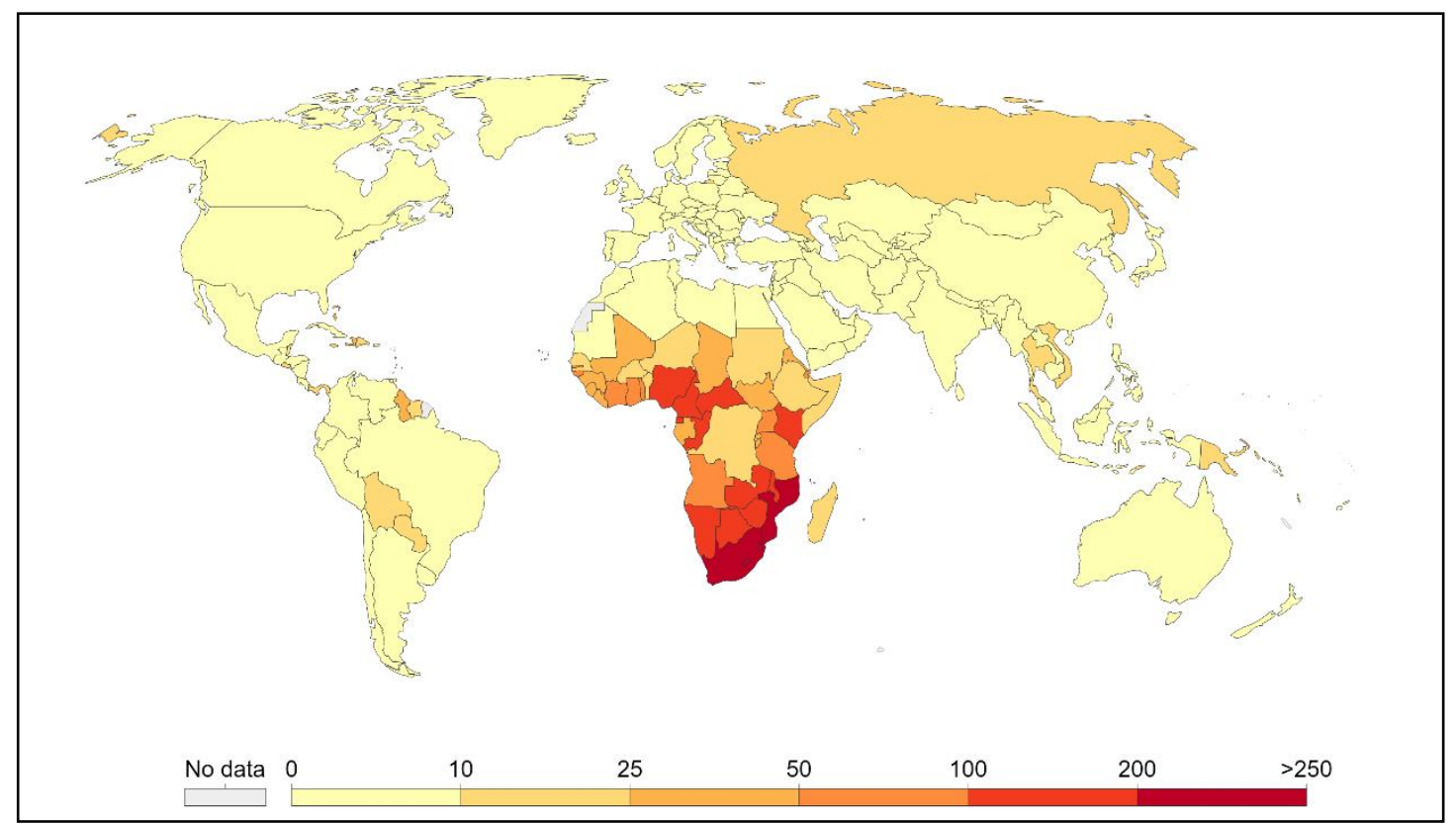

Sumber : Roser \& Ritchie, 2019

Rajah 2. Anggaran kes kematian akibat AIDS di seluruh dunia tahun 2017

Jumlah kematian akibat HIV/AIDS sebenarnya menurun hampir setiap tahun. Pada tahun 2016 sahaja, jumlah kes kematian direkodkan sebanyak 1.0 juta orang dan menurun pada tahun 2017 (940,000 orang) dan 2018 (770,000 orang) (WHO, 2016; 2017; 2018). Pengurangan ini adalah usaha gigih dan berterusan banyak pihak yang berjaya menghasilkan ubat atau vaksin antiretroviral. Kawasan di sub-Sahara masih mengekalkan status sebagai zon yang paling tinggi mencatatkan jumlah kes kematian akibat HIV/AIDS di dunia seperti Rajah 2. Di negara maju seperti Amerika dan wilayahnya yang lain, menjelang akhir tahun 2000 sahaja, kes kematian akibat HIV/AIDS yang direkodkan ialah lebih daripada 450,000 orang. Peningkatannya dikatakan berlaku berlaku hampir setiap tahun sejak awal HIV/AIDS dikesan iaitu awal 1980-an sehingga awal 1990-an. Bermula pada tahun 1996 dan 1997 barulah menampakkan penurunan yang ketara dan diluar jangkaan hasil penggunaan vaksin anti-retroviral (CDC, 2000).

Di Malaysia, kes kematian yang disebabkan oleh HIV/AIDS ini menunjukkan trend turun naik. Ada ketikanya mencatatkan kes yang tinggi dan ada ketika menjunam begitu ketara. Sejak mula dikesan sekitar tahun 1986 sehingga akhir tahun 2017, keseluruhan kes kematian yang 
disebabkan oleh HIV/AIDS telah mencecah 42,864 orang (Jadual 2). Penurunan demi penurunan jumlah kes kematian akibat HIV/AIDS di negara ini dipercayai juga hasil penggunaan vaksin atau terapi antiretroviral yang semakin meningkat. Secara tidak langsung mengurangkan kes kematian dalam kalangan penghidap HIV/AIDS.

Jadual 2. Anggaran jumlah jangkitan HIV dan kematian akibat AIDS di Malaysia sehingga tahun 2017

\begin{tabular}{lcc}
\hline \multirow{2}{*}{ Perkara } & \multicolumn{2}{c}{ Anggaran (Orang) } \\
\cline { 2 - 3 } & $\mathbf{1 9 8 6}$ - 2017 & $\mathbf{2 0 1 7}$ (Baru) \\
\hline Jumlah HIV Dilaporkan & 115,263 & 3,347 \\
Jumlah Kematian Akibat AIDS & 42,864 & 892 \\
Individu hidup dengan HIV positif & 72,399 & - \\
Kadar HIV (per 100,000 orang) & 28.4 (tahun 2002)* & 10.3 \\
Jangkitan HIV positif dalam kalangan wanita & 13,035 & 457 \\
Jangkitan HIV positif dalam kalangan kanak-kanak & 1,168 & 22 \\
\hline Nota: *kadar paling tinggi & & \\
Sumber: Kementerian Kesihatan Malaysia; Malaysia AIDS Council (MAC), 2017 &
\end{tabular}

Wanita yang hidup dengan HIV positif sebenarnya mengalami kerumitan dalam hidup mereka kerana pelbagai masalah berlaku secara tidak seimbang. Dijangkiti HIV positif bukan sahaja menjejaskan kesihatan mental, seksual dan reproduktif wanita, tetapi juga sumber manusia mereka (Orza et al., 2015). Selain itu, wanita ini turut mengalami kemurungan, insomania, menjadi malu, menyalahkan diri dan rasa terasing. Semuanya dikatakan berpunca daripada stigma dan peminggiran sosial. Stigma yang mensasarkan identiti wanita dijangkiti HIV postiif menyebabkan mereka memberi pandangan negatif terhadap HIV positif seperti mengaitkannya dengan kematian dan perkara negatif lain.

\section{Kaedah dan kawasan kajian}

Kajian ini menggunakan data sekunder dan primer. Data primer atau utama diperolehi melalui kaedah temu bual secara mendalam ke atas 20 orang wanita Melayu yang telah dijangkiti HIV positif dan menetap di sekitar daerah Besut (Terengganu), dan tiga jajahan di Pasir Puteh, Bachok dan Kota Bharu (Kelantan). Data sekunder berupa jurnal, bahan bertulis, bercetak, dan elektronik termasuklah statistik diperolehi daripada kajian kepustakaan dan pencarian atas talian turut digunakan untuk mengukuhkan lagi dapatan kajian ini.

Rasionalnya pemilihan tempat ini sebagai lokasi kajian adalah kerana banyak kes-kes yang tidak sihat dilaporkan berlaku seperti meminum minuman keras, pengedaran dan penagihan dadah yang tinggi. Malah, Agensi Dadah Kebangsaan (AADK) Terengganu sendiri ada mengeluarkan statistik bahawa, bilangan penagih di Daerah Besut sahaja seramai 445 orang antara paling tinggi berbanding daerah lain di Terengganu seperti di Kemaman 351, Kuala Terengganu 229, Dungun 188, Hulu Terengganu 128 dan Setiu 91 orang (Bernama, 2010). Peningkatan jumlah ini dikaitkan dengan kebanjiran warga asing yang bekerja sebagai nelayan terutamanya daripada Thailand, Myanmar dan Vietnam (Mashrom, 2018). Tambahan lagi, di lokasi ini adanya jeti pendaratan ikan Lembaga Kemajuan Ikan Malaysia (LKIM) di Kuala Besut (Terengganu) dan Tok Bali (Kelantan). 
Nelayan asing yang datang bekerja di lokasi ini (sama ada secara sah atau haram) turut membawa budaya tidak sihat di negara asal mereka seperti membawa masuk bahan terlarang seperti minum keras dan dadah sekali gus mempengaruhi penduduk tempatan serta nelayan tempatan (The Malaysian Times, 2013). Golongan muda tempatan turut terlibat sama, melepak dan bergaul dengan nelayan asing hinggakan kes penggunaan dadah dalam kalangan pemuda dan nelayan tempatan semakin meningkat. Walaupun aktiviti berisiko tinggi banyak berlaku di Besut, namun pengkaji menghadapi kesukaran untuk mendapatkan penghidap HIV positif wanita (hanya 2 orang informan sahaja). Sebagai langkah penyelesaian, pengkaji meluaskan kawasan kajian ke beberapa Jajahan di negeri Kelantan dan perbandingan di antara keduanya tidak dapat dibuat kerana tidak semua daerah serta jajahan yang terlibat.

Pemilihan kawasan di sebelah di Kelantan turut dianggap sebagai kawasan pesisir kerana rata-rata penduduknya bekerja sebagai nelayan serta menjadi tumpuan nelayan asing. Di sebelah Kelantan, nelayan warga asing lebih berani apabila turut mencuri hasil tanaman penduduk tempatan seperti tembikai dan dibawa naik ke atas bot dan berlegar secara berkumpulan keluar dari pelabuhan serta berjalan kaki sehingga lima kilometer ke dalam kampung tanpa rasa takut (Utusan Online, 2014).

\section{Hasil kajian dan perbincangan}

Hidup bertemankan HIV positif dianggap suatu yang menggerun dan menakutkan bagi seseorang individu, terutamanya penghidap wanita. Ini kerana, bagi mereka HIV positif dianggap sebagai 'bom jangka' dan seseorang penghidap boleh meninggal dunia pada bila-bila masa sahaja walaupun mereka sedar penyakit lain juga boleh menyebabkan kematian dalam masa yang singkat seperti jangkitan kencing tikus dan jangkitan kuman. Namun demikian, dijangkiti HIV positif, situasinya dikatakan berbeza. Oleh kerana terlalu memikirkan soal kematian, menyebabkan kehidupan harian penghidap wanita terjejas teruk sehinggakan tanggungjawab dan peranan mereka tidak dilakukan sebaiknya seperti sebelum dijangkiti.

Tidak dinafikan, apabila dijangkiti HIV positif jarang ada yang boleh menerima kenyataan. Tambah-tambah lagi apabila dijangkiti pada usia yang muda, tidak terlibat dengan aktiviti berisiko dan disebabkan oleh suami/pasangan sendiri yang paling dipercayai. Disebabkan oleh sifat HIV positif itu sendiri yang membawa konotasi negatif serta sering dikaitkan dengan perkara-perkara yang tidak elok turut mempengaruhi penerimaan penghidap terhadap jangkitan HIV positif. Akibatnya, penghidap merasakan peluang mereka dalam bidang pekerjaan, pendidikan, membuat keputusan, perkahwinan, mengandung dan melahirkan anak sudah berkurang atau sudah tiada. Inilah yang berlaku ke atas 20 orang informan (Jadual 3) wanita Melayu dalam kajian ini.

Hampir kesemua informan yang ditemu bual mendedahkan bahawa, setelah didiagnosis dan disahkan sebagai penghidap HIV positif, perkara pertama yang mereka fikirkan adalah kematian. Bagi informan, hanya kematian sahaja yang bermain dalam minda mereka kerana semua orang memperkatakan benda yang sama termasuklah adik beradik, saudara mara, rakan-rakan, jiranjiran malahan doktor sendiri. Antara pendedahan lain yang dinyatakan oleh informan termasuklah 'hanya kematian jalannya', 'hanya menunggu mati', 'dimandikan dengan klorok apabila mati' serta pelbagai pandangan negatif lain. Maklumat yang salah tentang jangkitan HIV positif secara tidak langsung mempengaruhi pandangan informan secara keseluruhannya walaupun sekarang ini seseorang penghidap boleh bertahan dan hidup sehingga berbelas-belas tahun walaupun dengan HIV positif. 
Jadual 3. Latar belakang informan

\begin{tabular}{|c|c|c|c|c|c|c|}
\hline \multirow[t]{2}{*}{ Informan } & \multirow{2}{*}{$\begin{array}{l}\text { Umur } \\
\text { (Thn) }\end{array}$} & \multicolumn{2}{|c|}{ Perkahwinan } & \multirow{2}{*}{$\begin{array}{l}\text { Jangkitan } \\
\text { (Thn) }\end{array}$} & \multirow[t]{2}{*}{ Pendidikan } & \multirow[t]{2}{*}{ Pekerjaan } \\
\hline & & Status & Kekerapan \& Umur & & & \\
\hline Rozita & 28 & Berkahwin & $\begin{array}{l}\mathrm{P} 1^{*}=21 \mathrm{Thn} \\
\mathrm{P} 2^{*}=27 \mathrm{Thn}\end{array}$ & 7 & Ting. 1 & Suri Rumah \\
\hline Aisyah & 30 & Berkahwin & $\begin{array}{l}\mathrm{P} 1=20 \mathrm{Thn} \\
\mathrm{P} 2=28 \mathrm{Thn}\end{array}$ & 6 & PMR-U & Suri Rumah \\
\hline Ani & 33 & Berkahwin & $\begin{array}{l}\mathrm{P} 1=20 \mathrm{Thn} \\
\mathrm{P} 2=28 \mathrm{Thn}\end{array}$ & 9 & SPM & Tukang Jahit, Butik \\
\hline Ana & 34 & Ibu Tunggal & $\mathrm{P} 1=22 \mathrm{Thn}$ & 5 & Ting. 5 & Pengasuh, Buat Kuih \\
\hline Ifah & 36 & Ibu Tunggal & $P 1=22 \mathrm{Thn}$ & 14 & SPM & Pengasuh \\
\hline Mimi & 37 & Ibu Tunggal & $\mathrm{P} 1=23 \mathrm{Thn}$ & 2 & SPM & Tukang Jahit, Butik \\
\hline Nora & 37 & Ibu Tunggal & $\mathrm{P} 1=14 \mathrm{Thn}$ & 6 & Ting. 3 & Tukang Sapu \\
\hline Hidayah & 37 & Ibu Tunggal & $\begin{array}{l}\mathrm{P} 1=24 \mathrm{Thn} \\
\mathrm{P} 2=32 \mathrm{Thn}\end{array}$ & 10 & SPM & $\begin{array}{l}\text { Kedai Runcit, } \\
\text { Kerja Kampung }\end{array}$ \\
\hline Ziela & 37 & Berkahwin & $\begin{array}{l}\mathrm{P} 1=21 \mathrm{Thn} \\
\mathrm{P} 2=28 \mathrm{Thn}\end{array}$ & 8 & SPM & Stesen Minyak \\
\hline Mazni & 38 & Berkahwin & $\begin{array}{l}\mathrm{P} 1=20 \mathrm{Thn} \\
\mathrm{P} 2=35 \mathrm{Thn}\end{array}$ & 8 & SPM & Tukang Sapu \\
\hline Shikin & 38 & Berkahwin & $\mathrm{P} 1=23 \mathrm{Thn}$ & 5 & SPM & Kedai Makan \\
\hline Habibah & 39 & Berkahwin & $\mathrm{P} 1=20 \mathrm{Thn}$ & 5 & SPM & Suri Rumah \\
\hline Maimun & 39 & Ibu Tunggal & $\mathrm{P} 1=30 \mathrm{Thn}$ & 7 & SPM & Pembantu Tadika \\
\hline Atikah & 40 & Ibu Tunggal & $\mathrm{P} 1=20 \mathrm{Thn}$ & 13 & SPM & Menoreh Getah \\
\hline Suhaila & 41 & Berkahwin & $\begin{array}{l}\mathrm{P} 1=22 \mathrm{Thn} \\
\mathrm{P} 2=39 \mathrm{Thn}\end{array}$ & 5 & Diploma & Cikgu Tadika \\
\hline Fatin & 43 & Ibu Tunggal & $\mathrm{P} 1=15 \mathrm{Thn}$ & 15 & SPM & Tukang Jahit \\
\hline Tina & 45 & Ibu Tunggal & $\mathrm{P} 1=18 \mathrm{Thn}$ & 5 & SRP & Tidak Bekerja \\
\hline Siti & 49 & Ibu Tunggal & $\begin{array}{l}\mathrm{P} 1=16 \mathrm{Thn} \\
\mathrm{P} 2=37 \mathrm{Thn}\end{array}$ & 3 & SPM & Pembantu Pertubuhan \\
\hline Fatimah & 51 & Ibu Tunggal & $\begin{array}{l}\mathrm{P} 1=20 \mathrm{Thn} \\
\mathrm{P} 2=30 \mathrm{Thn}\end{array}$ & 8 & Darjah 6 & $\begin{array}{l}\text { Menoreh Getah, } \\
\text { Buat Kuih }\end{array}$ \\
\hline Sharifah & 53 & Ibu Tunggal & $\mathrm{P} 1=30 \mathrm{Thn}$ & 15 & SPM & Tukang Jahit \\
\hline
\end{tabular}

Nota: P1 = Perkahwinan Pertama; P2 = Perkahwinan Kedua

Sumber: Kerja lapangan

Malahan ada juga penghidap yang tidak mengalami sebarang simptom atau sakit-sakit lain selama mana selepas mereka dijangkiti HIV positif. Rata-rata informan telah dijangkiti HIV antara tempoh 2 hingga 15 tahun dan orientasi seksual (heteroseksual) menjadi penyebab utama mereka dijangkiti kerana tidak menggunakan kondom dengan pasangan/suami yang terlibat dengan aktiviti berisiko. Dari segi umur informan, mereka berumur antara 28 hingga 53 tahun dan sebahagian besarnya masih pada tingkat umur produktif untuk bekerja, mengandung dan melahirkan anak.

Seseorang penghidap wanita berkemungkinan besar mempunyai pandangan yang berbeza tentang HIV positif seandainya mereka mendapat maklumat yang betul dan tepat mengenainya. Walaupun tahap pendidikan informan yang rendah atau sederhana, dengan kecukupan dan keberkesanan maklumat yang disampaikan oleh pihak berkepentingan turut mampu mengubah pandangan mereka tentang jangkitan ini. Ini kerana, pandangan-pandangan yang diberikan oleh informan mempunyai perkaitan dengan perlakuan mereka sama ada ke arah yang positif atau negatif. Pandangan positif boleh memberi kekuatan emosi kepada informan untuk terus bertahan dan menjalani kehidupan seperti biasa walaupun dengan status HIV positif. Manakala pandangan 
negatif menyebabkan tugasan dan peranan hakiki mereka seperti menjaga kesihatan diri, anakanak kecil, ibu ayah dan suami/pasangan turut terjejas.

\section{Pandangan negatif tentang HIV Positif}

Setiap informan yang dijangkiti HIV positif mempunyai pandangan tersendiri mengenai apa yang berlaku ke atas diri mereka. Pandangan ini dianggap penting kerana boleh mempengaruhi perlakuan serta tindakan mereka, terutamanya dalam tempoh-tempoh awal jangkitan (tempoh penerimaan) HIV positif. Dijangkiti HIV positif, jarang ada informan yang boleh menerimanya sama ada yang pernah terlibat dengan aktiviti berisiko (seperti penagihan dadah, pelacuran, seks bebas, seks songsang) atau yang tidak pernah terlibat langsung. Ini kerana, kehidupan selepas dijangkiti HIV positif banyak cabaran dan dugaan, antaranya stigma dan diskriminasi. Stigma dan diskriminasi boleh dianggap sebagai hukuman yang paling berat bagi informan kerana dengannya kehidupan mereka boleh terjejas secara holistik. Stigma dan diskriminasi juga boleh datang daripada pelbagai pihak, keadaan dan tempat, termasuklah ahli keluarga sendiri. Maka tidak hairanlah sekiranya informan banyak memikirkan soal kematian setelah disahkan sebagai penghidap HIV positif. Malah soal kematian adalah perkara pertama yang difikirkan oleh informan. Selain kematian, ada juga informan yang mengaitkan jangkitan HIV positif dengan situasi atau perkara negatif lain seperti "orang akan benci, orang akan hina, penyakit orang takut, penyakit orang malu”(Jadual 4).

Jadual 4. Pandangan mengenai jangkitan HIV positif

\begin{tabular}{l} 
Kepercayaan Negatif Mengenai HIV Positif \\
\hline Mati tidak boleh bawa balik ke rumah \\
Penyakit orang benci, malu, kotor, rendah diri \\
Mati takde siapa peduli, mandi dengan klorok \\
Penyakit orang takut, takut tido esok tak bangun \\
Kena HIV positif, mesti mati, tunggu mati \& tak lama lagi akan mati \\
Balasan Tuhan, sebab tak dengar nasihat keluarga, lawan mak dengan ayah \\
Sumber: Kerja lapangan
\end{tabular}

\section{HIV Positif dan kematian}

Menurut sesetengah informan, mereka mengakui bukan sengaja mengaitkan HIV positif dengan kematian, tetapi ianya berlaku secara sendirinya. Ini kerana, HIV positif dan mati sering diperkatakan oleh semua orang dan mereka sendiri pernah melihat apa yang berlaku ke atas individu yang dijangkiti HIV positif. Rakan-rakan, jiran tetangga, ahli keluarga, masyarakat sekeliling, media massa atau media cetak banyak mempengaruhi pandangan informan tentang jangkitan HIV positif ini. Mengukuhkan lagi pandangan ini ialah apabila ada segelintir doktor yang mengatakan benda yang sama kepada informan seperti 'tunggu mati sahajalah kalau sudah dijangkiti HIV positif'. Maklumat-maklumat seperti ini sebenarnya sangat mempengaruhi pandangan informan tentang HIV positif walaupun secara realitinya tidak berlaku sedemikian. Situasi pada hari ini sebenarnya sudah berubah dan ada dalam kalangan informan yang boleh bertahan sehingga berbelas-belas tahun lamanya walaupun dengan status HIV positif. Namun, disebabkan oleh kekurangan atau maklumat yang tidak tepat menyebabkan informan terus mengaitkan HIV positif dengan kematian. Beberapa orang informan terpilih iaitu Kak Atikah, 
Kak Ziela, Kak Siti dan Kak Sharifah mengalami situasi yang hampir sama dan mereka menceritakan pengalaman mereka apabila disahkan sebagai penghidap HIV positif.

Menurut informan Kak Atikah (bukan nama sebenar), HIV dan AIDS adalah sama. Apabila menyebut atau mendengar perkataan HIV, hanya AIDS yang terbayang dalam mindanya. Malah, orang kampung sendiri pun kadang-kadang tidak tahu secara terperinci mengenai HIV positif atau AIDS dan bagi mereka semuanya sama. Walaupun tidak tahu banyak mengenai HIV positif, namun informan tahu cara jangkitan yang biasa berlaku iaitu (1) main dadah; (2) main perempuan atau betina; dan (3) anak dengan ibu. Bagi informan ini, mula-mula mengetahui diri dijangkiti HIV positif adalah ketika membuat pemeriksaan kandungan. Disebabkan oleh perasaan terlalu terkejut, takut dan risau (termasuk kandungannya), informan hanya memikirkan soal kematian sahaja dan pernah terfikir untuk membunuh diri kerana tidak boleh menerima kenyataan. Kak Atikah mendedahkan lagi;

[Dialek Kelantan]

“...dulu kalu sebut pasal HIV, sayo tahu nyakit AIDS jer lah, tu jah wat saya tahu. Sebelum keno dulu, sayo tahu la 3 jenis jangkitan dio, main dadoh, main tino, lepas tu anok dengan ibu. Sayo mulo-mulo tahu dulu maso ngandung, maso tu kandungan sayo 3 bulan. Lepas ambik daroh misi gi turut sayo dio kato sayo ado HIV. Lepas tu sayo kejut, raso mace takdop harapan doh nok hidup, doktor pun kato tunggu maut jer. Maso tu ado jugo mikir raso lebih baik mati daripada hidup. Rajin jugo mikir aku bunuh diri kan, sebab takut. Banyo mikir mati, mikir anok lagu mano kalau sayo mati..."

Bagi informan Kak Ziela (bukan nama sebenar) pula, situasinya hampir sama apabila memikirkan kematian sahaja ketika disahkan menghidap HIV positif. Bagi informan, masyarakat sering mengaitkan jangkitan HIV positif dengan kematian dan semua orang takut, benci serta sebolehnya tidak mahu bersemuka dengan individu yang dijangkiti kerana khuatir virus HIV boleh tersebar. Selain itu, jarang ada orang yang boleh menerima kehadiran penghidap HIV positif kerana mereka ini dianggap sebagai golongan yang terlibat dengan aktiviti tidak bermoral, perlu dijauhi, dipulau dan disingkirkan. Selain memikirkan mati, informan turut mengakui sangat terkejut dan takut sehingga tidak boleh berkata-kata. Menurut informan Kak Ziela lagi;

[Dialek Kelantan]

“...Maso sayo mulo-mulo ado sakit nie, meme tak leh nok royak ko ore, raso macemace, takdop fikir lain, sayo fikir nok mati so jah, fikir mati jer. Sebelum nie kan mesti doh, kalau keno HIV positif, mesti mati. Mace-mace mano keno pun, mesti mati jer la. Takdop fikir lain doh. Lepas pado keno tu, nok kijo malas, nok make nasi malas, serba serbi malas, nok buat gotu, buat goni, semua malas...Mula-mula sayo tahu keputuse itu, mace 'pecoh hati' sayo. Tak tahu nok royak gapo, raso mace nok mati. Maso tu sayo hanya mampu nangis, fikir mati jah sebab penyakit ini kalu keno, mati jer lah jale dio..."

Manakala informan ketiga iaitu Kak Siti (bukan nama sebenar) situasinya sama dengan situasi yang dilalui dengan informan kedua iaitu Kak Ziela. Selain memikirkan 'mati' ketika mula-mula disahkan dijangkiti HIV positif, informan juga tidak mampu berkata-kata kerana terlalu terkejut dan rebah di atas katil hospital setelah diberitahu oleh doktor mengenai jangkitan tersebut. Sampai sekarang informan seolah-olah tidak percaya dan tidak menyangka dijangkiti HIV walaupun tidak pernah terlibat dengan apa-apa perkara yang tidak elok serta dijangkiti 
melalui suami yang dipercayainya. Menurut informan lagi, pada masa itu hanya mati dan menunggu mati sahaja yang berlegar-legar dalam fikiranya. Kak Siti menceritakannya lagi;

[Dialek Kelantan]

“...Sayo lepas pado tau tu gak, paka reboh ping atas katil tak bangun-bangun, paka tak ingat gapo-gapo doh. Maso tu supo jadi tak leh nok kecek gapo-gapo, supo fikir tunggu mati jah....Maso mulo-mulo tahu tu, jerit tak leh nok kato...Setiap kali sayo duduk sore, ado jugo mari mikir pasal mati, mikir kalu sayo mati, ore lain akan tahu kito ado HIV positif, kalu mati di spital, tak boleh bawa balik rumoh, mandi dengan klorok, hantar ke kubur hok siap doh ..."

Informan seterusnya, iaitu Kak Sharifah (bukan nama sebenar) menceritakan bagaimana pengalamannya yang tidak boleh menerima kenyataan dan hampir membunuh diri. Pada masa itu, kematian sahaja yang difikirkan apabila doktor yang membuat pemeriksaan mengatakan HIV positif ada di dalam dirinya. Pada ketika itu juga, informan menyatakan banyak tertekan, termenung, menangis dan sentiasa berada dalam ketakutan, terutamanya setiap kali mahu tidur malam. Ini kerana, informan banyak berfikir sama ada masih sedar atau tidak untuk keesokan harinya. Informan menceritakan lagi seperti berikut:

\begin{abstract}
[Dialek Kelantan]
“...Reaksi sayo maso mulo-mulo tahu meme terkejut, sayo tak sedar sayo katok suami. Maso tu sayo tak sedar campur dengan terkejut. Lepas sayo tahu, sayo balik meme tak kering air mato la jerit. Pernah jugo terfikir nok bunuh diri.Raso mace takde guno aku hidup.Awal-awal tahu dulu, bilo nok tido malam, esok nie boleh bangun ke dok, mungkin male nie tutup mato, bangun ke tidok. Tapi bilo bangun pagi, oo aku hidup lagi. Tiga tahun sayo alami benda macam nie. Bila nak tido, takut esok takleh bangun sebab mati..."
\end{abstract}

Pandangan-pandangan yang diberikan oleh informan ini memperlihatkan bahawa, mereka sebenarnya kekurangan maklumat berkaitan dengan HIV positif. Apa sahaja yang diperkatakan oleh orang sekeliling atau yang diperolehi melalui media-media massa dan elektronik dijadikan sebagai rujukan. Informan percaya dan menerima bulat-bulat apa yang diperkatakan atau yang diperolehi kerana mereka berada pada fasa yang dianggap sebagai 'fasa panik'. Pada fasa ini, mereka cuba untuk menafikan apa yang berlaku dan dalam masa yang sama berusaha mendapatkan maklumat berkaitan dengan HIV positif seperti mendapat pandangan daripada ahli keluarga, rakan-rakan, jiran, melalui pembacaan dan sumber internet. Kadang-kadang maklumat yang diperolehi itu banyak yang tidak benar dan secara tidak langsung mempengaruhi pandangan mereka. Maka tidak hairanlah sekiranya ramai dalam kalangan informan yang mengaitkan HIV positif dengan kematian dan perkara negatif lain. Selagi tidak mendapat maklumat yang betul, selagi itulah juga informan dan orang ramai berpandangan negatif terhadap HIV positif.

\title{
Kesimpulan
}

Setiap tahun jumlah orang yang hidup dengan HIV positif semakin meningkat walaupun jumlah kes baru semakin berkurang. Peningkatan ini mempunyai kaitannya dengan penambahan jangka 
hayat seseorang penghidap HIV positif hasil kemajuan kaedah rawatan dan penggunaan vaksin antiretroviral. Walaupun jangka hayat seseorang penghidap semakin meningkat, namun pemahaman berkaitan jangkitan ini sebenarnya masih berada pada tahap yang rendah dan sederhana. Disebabkan oleh itu juga, masih ada dalam kalangan penghidap HIV positif dan AIDS yang masih tidak jelas dan faham tentang jangkitan ini walaupun sudah berpuluh atau berbelas tahun dijangkiti. Apabila usia HIV positif sudah menjangkau tempoh 5 hingga 10 tahun, sepatutnya penghidap sudah faham, jelas dan mendapat banyak maklumat tentangnya. Malah penghidap-penghidap ini boleh dianggap sebagai 'senior' dan boleh menjadi sumber rujukan kepada penghidap-penghidap baru, terutamanya yang masih berada pada fasa kritikal seperti penafian, pengasingan diri, putus asa dan kemungkinan yang lain. Selain itu, pendedahan, perkongsian dan penyebaran maklumat yang berterusan, secara tidak langsung membantu mengubah pandangan serta persepsi penghidap dan juga masyarakat umum tentang jangkitan HIV positif. Situasi hari ini, dijangkiti HIV positif tidak semesti 'mati', malah penghidap ini mampu bertahan dan hidup sehingga berpuluh tahun tanpa sebarang masalah penyakit lain. Penghidap yang dijangkiti juga, tidak semestinya terlibat dengan perkara-perkara tidak bermoral, tetapi ada juga yang menjadi mangsa seperti wanita dan gadis remaja.

\section{Rujukan}

Aishah @ Eshah Hj. Mohamed. (2002). Wanita, ketaksamaan sosial dan risiko jangkitan AIDS. Akademika, 61, 71-89.

CDC. (2000). http://www.cdc.gov/ [18 March 2016].

Current World Population. (2019). https://www.worldometers.info/world-population/ [15 September 2019].

Doggett, E.G., Lanham, M., Wilcher, R., Gafos, M., Karim, Q.A., \& Heise, L. (2015). Optimizing HIV prevention for women: a review of evidence from microbicide studies and considerations for gender-sensitive microbicide introduction. Journal of the International AIDS Society, 18(1), 20536. doi:10.7448/IAS.18.1.20536

Giffin, K., \& Lowndes, C. (1999). Gender, sexuality and the prevention of sexually transmissible diseases. A Brazilian study and clinical practice. Social Sciences and Medicine, 48(3), 283-292.

Kementerian Kesihatan Malaysia. (2017). County Progress Report on HIV/AIDS. http://www.moh.gov.my/resources/index/Penerbitan/Laporan/Country_Progress_Report_O n_HIV_AIDS_2018.pdf [1 Mac 2019].

Khalid Ghailan A, Jusoh M. Rizal, Sharifa Ezat F. Ibrahim, Jalal Halil, \& Aljunid S. (2010). Impact of HIV/AIDS morbidity on households economy in Malaysia. Global Journal of Health Science, 2(2), 142-153. Retrieved from http://www.ccsenet.org/journal/index.php/ gjhs/article/view/6733/5884

Komwa, M.K., Jacobsen, K.H., \& Parker, D.C. (2010). HIV/AIDS-associated beliefs and practices relating to diet and work in southeastern Uganda. Journal of health, population, and nutrition, 28(1), 76-85. doi:10.3329/jhpn.v28i1.4526

Malaysian AIDS Council. (2014). Snaphot Of HIV \& AID in Malaysia 2013. Kuala Lumpur.

Malaysian AIDS Council. (2017). Snapshot of HIV \& AIDS in Malaysia 2017. Kuala Lumpur. Retrieved from https://www.mac.org.my/v3/snapshot-of-hiv-aids-in-malaysia-2017/ 
Mashrom Muda \& Rahimah Abdul Aziz. (2015). Wanita dan HIV/AIDS di Malaysia: Punca jangkitan dari aspek sosiobudaya. Geografia-Malaysia Journal of Society and Space, 11(1), 73-86.

Mashrom Muda. (2018). Wanita dan jangkitan HIV positif: Kualiti kehidupan dan pemerkasaan diri. (Tesis PhD), Program Antropologi dan Sosiologi, Pusat Pengajian Siswazah, Universiti Kebangsaan Malaysia (Tidak diterbitkan).

Monagan, S.L. (2010). Patriarchy: Perpetuating the practice of female genital mutilation. Journal of Alternative Perspectives in the Social Sciences, 2(1), 160-181. Retrieved from: http://www.japss.org/upload/8._Sharmon\%5B1\%5D.pdf

Orza, L., Bewley, S., Logie, C.H., Crone, E.T., Moroz, S., Strachan, S., ... Welbourn, A. (2015). How does living with HIV impact on women's mental health? Voices from a global survey. Journal of the International AIDS Society, 18(Suppl 5), 20289. doi:10.7448/IAS.18.6.20289

Puri, M., Tamang, J., \& Shah, I. (2011). Suffering in silence: Consequences of sexual violence within marriage among young women in Nepal. BMC Public Health, 11, 29. doi:10.1186/1471-2458-11-29

Roser, M., \& Ritchie, H. (2019). HIV/AIDS. https://ourworldindata.org/hiv-aids [15 September 2019].

UNAIDS. (2004). Women and HIV/AIDS: Confronting the crisis. Available from:http://www. avert.org/women-hiv-aids.htm [19 Ogos 2010].

UNAIDS. (2018). UNAIDS report on the global AIDS epidemic. Available from:http://www. unaids.org/globalreport/Global_report.htm [12 Ogos 2010].

WHO. (2009). Women and health: Today's evidence tomorrow's agenda. Geneva: World Health Organization.

WHO. (2014). Global Health Observatory (GHO) Data. http://www.who.int/gho/hiv/en/

WHO. (2016). Global AIDS Update. https://www.who.int/hiv/pub/arv/global-AIDS-update2016_en.pdf [1 Mac 2019].

WHO. (2017). Data and Statistic. https://www.who.int/hiv/data/en/

WHO. (2018). Global Health Observatory (GHO) Data. https://www.who.int/gho/hiv/epidemic status/cases_all/en/

Winkvist, A., \& Akhtar, H.Z. (2000). God should give daughters to rich families only: Attitudes towards childbearing among low-income women in Punjab, Pakistan. Journal of Social Science \& Medicine, 51, 73-81. 